\title{
Leadership and Knowledge Sharing
}

\author{
Robert Bradshaw \\ De Montfort University, Leicester, LE1 9BH \\ Mondher Chebbi \\ De Montfort University, Leicester, LE1 9BH \\ Hulya Oztel \\ De Montfort University, Leicester, LE1 9BH
}

\begin{abstract}
Knowledge processes and leadership and management have both been central to discussions within the academic literature. While the number of empirical studies looking at the interaction between these dimensions has been limited. Within this study structural equation modelling using SMART PLS is utilised to identify the implications when determining the most effective leadership styles for achieving knowledge transfer. It was found that a combined leadership approach was the most effective when considering knowledge processes through the SECI model. The study contributes to the literature by allowing us to identify specific leadership style attributes being matched to specific knowledge process stages for achieving maximum impact. The study also allowed us to test empirically the suitability of the leadership and knowledge constructs within the UAE.
\end{abstract}

Keywords: Middle East, Leadership styles, knowledge processes.

\section{Introduction}

One of the most cited elements of leadership that contributes to knowledge sharing in schools is the style of the leader (Leithwood et al., 1999). A leadership style is the behaviour a leader exhibits while guiding organizational members in appropriate directions (Certo and Certo, 2006). Leaders improve their style over a period of time due to experience, education, and training. For many years HRM researchers have tried to explain how leaders' style or behaviour relates to effectiveness (Dessler, 2004). Transformational leadership has been demonstrated as an effective leadership style in leading schools (Leithwood et al., 1999), having been shown to have a significant influence on subordinates' behaviour and organizational outcomes (Tickle et al, 2005).

This study makes several important contributions to the existing literature and knowledge. First of all, it integrates two previously relatively disparate fields of 
knowledge sharing and leadership processes from an empirical perspective. Secondly, the study empirically proves that transformational leadership strongly correlates with knowledge sharing. Thirdly, the study also establishes a strong relationship between contingent reward leadership behaviour and knowledge sharing, thus highlighting the importance of such a type of leadership style for successfully developing HR within a learning organization. Fourthly, the study provides empirical confirmation for the contingent perspective towards leadership styles and learning (Vera and Crossan, 2004), which claims that the most effective strategic leaders are those best able to function in both transformational and transactional mode, depending upon the situation. Finally, the study expands the scope of empirical research by examining leadership and knowledge sharing in the context of private schools in Dubai. By testing existing (predominantly Anglo Saxon) theories of leadership and knowledge sharing process in different environment; culturally, hierarchically, economically, and politically. The study, therefore, enhances the international generalisabilty and validity of these theories and constructs.

\section{Theoretical Framework}

Transformational leaders have been shown to evoke a range of actions and feelings with subordinates. For instance; they encourage followers to do more than required (Sosik et al, 2002), are proactive and help followers to attain unexpected goals (Antonakis et al, 2003), they move followers beyond immediate self interest (Bass, 1999). The transformational leaders are models of integrity and fairness, set clear goals, have high expectations, provide support and recognition, stir the emotions and passions of people, and encourage people to look beyond their self-interest to reach for the improbable (Pierce and Newstorm, 2008; Bass, 1985).

Transformational leaders can create significant organizational change and act as change agents, foster higher level of intrinsic motivation, and loyalty among followers, introduce a new image or view of the future and create a commitment to this image among followers (Kinicki and Kreitner, 2008). Transformational leadership is comprised of five dimensions which are idealized influence (attribute and behaviour), inspirational motivation, intellectual stimulation, and individualized consideration.

Idealized influence describes the degree in which leaders are perceived as an inspiring role model (Moss and Ritossa, 2007). Idealized influence consists of two forms: idealized influence attribute in which leaders receive trust plus respect, and idealized influence behaviour in which leaders exhibit excellent behaviour and might sacrifice their own needs to improve the objectives of their workgroup (Moss and Ritossa, 2007).

Inspirational motivation describes the degree in which the leader states a vision that is attractive and encouraging to followers (Judge and Piccolo, 2004). Leaders strengthen followers by viewing the future by optimism (Antonakis et al, 2003), and act in ways that motivate those around them by providing meaning and challenge to their followers' work (Bass, et al, 2003). 


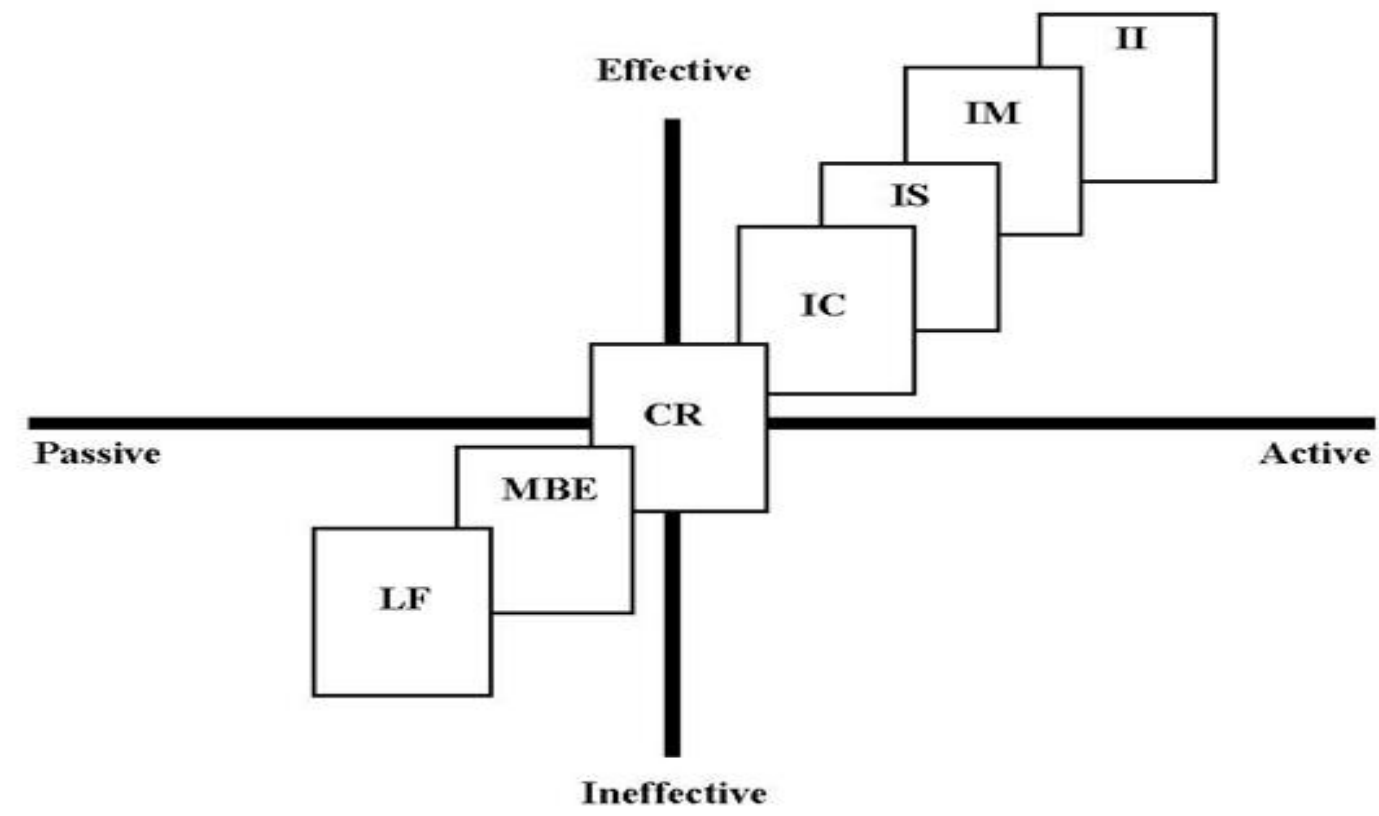

Source: Adapted from Bass, 1994

Intellectual stimulation explains the degree in which the leader stimulates their followers' endeavour to be innovative and creative (Limsilla and Ogunlana, 2008), and consider old organizational problems with a new perspective (Moss and Ritossa, 2007).

Individualized consideration refers to the degree in which leaders providing support, encouragement, and coaching to followers (Yukl, 2006). The leaders listen carefully to the individual needs of followers and may delegate certain responsibilities to help followers grow through personal challenges (Bass and Avolio, 1994; Bass et al, 2003; Judge and Piccolo, 2004; Northouse, 2007).

Transactional leadership forms the second part of transformational leadership theory. Transactional leadership concentrates on the exchanges that occur between leaders and their followers (Northouse, 2007), which helps follower to fulfil their own interests (Bass, 1999). Transactional leaders clarify followers' responsibilities, their performance objectives, and their tasks that must be completed (Eptropaki and Martin, 2005). This type of leadership deals with maintaining the current situation and motivating people through contractual agreement (Bass, 1985; Jung et al, 2008). Transactional leaders direct followers to achieve established goals by explaining goals, role and task requirements (Armandi et al, 2003). This leadership style tends to emphasize extrinsic rewards, such as monetary incentives and promotion (Jung et al, 2008). Transactional leaders prefer to avoid risk, and focus on efficiency (Levy et al, 2002). Transactional leadership is comprised of three dimensions which are contingent reward, management-by-exception active, and management-by-exception passive. 
Contingent reward describes the degree in which the leader determines rewards in exchange with followers' efforts to satisfy organizational goals. It includes clarification of the work required to obtain rewards and the use of incentives to influence motivation. Leaders must clarify the expectations and present recognition when goals are accomplished (Limsila and Ogunlana, 2008; Yukl, 2006).

Management-by-exception active explains the degree in which a leader watches followers closely for mistakes or role violations (Northouse, 2007). Active leaders check follower behaviour, predict problems, and take corrective actions before the behaviour makes severe difficulties (Judge and Piccolo, 2004).

Management-by-exception passive explains the degree in which leaders wait for deviances, mistakes, and errors to happen and then take corrective actions (Judge and Piccolo, 2004). They do not actively seek out deviations from desired performance and only take corrective action when problems occur (Pounder, 2001). This type of leader avoids describing agreements, explaining expectations and standards to be achieved by subordinates, but will intervene after particular problems become apparent.

\section{Knowledge Creation and Sharing}

Nonaka and Takeuchi (1995) describe how firms create and share new knowledge through four primary modes that involve the interaction of tacit and explicit knowledge: Socialisation is the process of sharing one's experience with another, thereby creating tacit knowledge in the form of mental models and technical skills. Tacit knowledge is shared among people through modelling and mentoring, conversation, workplace culture, and shared experiences. Externalisation converts tacit knowledge into explicit concepts. Firms do this by using metaphors, analogies, concepts or models. Knowledge created in formal educational settings such as in universities and in MBA programs fits in this category. Externalization is a process among individuals within a group (Nezafati, Afrazeh, and Jalali, 2009).

Internalisation involves turning explicit knowledge into tacit knowledge. Knowledge that has been generated by others is absorbed by another individual and internalized. Experiences through socialisation, externalisation and combination are internalised into individual tacit knowledge bases in the form of shared mental models or technical know-how. The internalisalization process transfers organization and group explicit knowledge across organizations (Nezafati et al, 2009). Knowledge in the tacit form is actionable by the owner. (Nonaka, 1994; Nonaka and Takeuchi, 1995).

The Combination process creates a new form of knowledge by combining two sources of explicit knowledge. For example, several reports may be integrated into a succinct summary report and entered into a database or knowledge base. Combination allows knowledge transfer among groups across organizations (Lemon and Sahota, 2004).

The subsections highlight the dimensions for SECI model for knowledge creation and sharing for this study. Four forms of transactions of knowledge creation and sharing were identified: tacit to tacit, explicit to explicit, tacit to explicit and explicit to tacit. The SECI model points out the channels for each transaction: Each type of 
knowledge can be converted. When viewed as a continuous learning process, the model becomes a clockwise spiral.

\section{Figure 2: SECI Model for Knowledge Creation and Sharing}

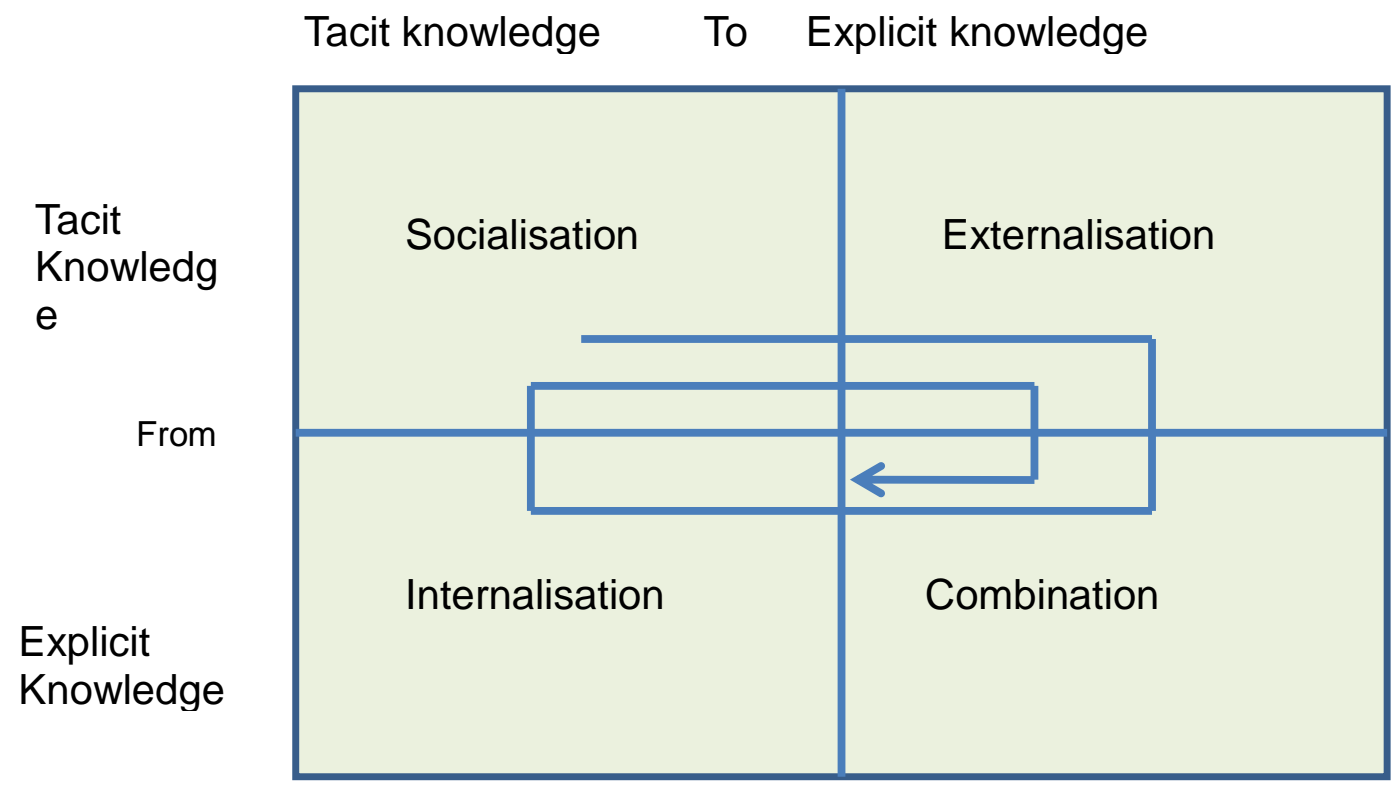

Source: SECI Model (Nonaka and Takeuchi 1995, pp.71).

\section{Leadership and Knowledge}

Chen, et al., (2004) examined the relationship between leadership behaviours and knowledge sharing in professional service firms in Taiwan and the United States. The results showed transformational leadership behaviours as a significant predictor of internal knowledge sharing, and Contingent reward leadership behaviours are significantly and positively correlated with both internal and external knowledge sharing.

However, Bock and Kim (2002) examined the factors that support or constrain the individual's knowledge sharing behaviour in the organizational context, and how they eventually influence the knowledge sharing behaviour. Their research results from the field survey of 467 employees of four large, public organizations show that expected rewards, expected associations, and expected contribution as the major determinants of the individual's knowledge sharing attitude, and this attitude as a determinant of the knowledge sharing behaviour.

Bock and Kim (2002) argued from a theoretical perspective, economic exchange theory also suggests that a person behaves after calculating the expected rewards and costs incurred by his or her behaviour. However, they argue that contrary to many researchers' expectations, their study shows that the attitude toward knowledge sharing is negatively related to the expected rewards. They add that expected rewards discourage the formation of a positive attitude toward knowledge sharing. 
In addition, Constant et al. (1994) argued that experienced workers learned that they should share their knowledge which was acquired from their work and training. Therefore, the author argues that workers may have a negative attitude toward receiving extrinsic benefits in return for knowledge sharing behaviour which they perceive as a normal business activity.

While clear arguments for the influence of transformational leadership on knowledge sharing exist, as is shown above, the role of transactional leadership is not so clear. Vera and Crossan (2004) propose a theoretical model where good leaders are those that know how to switch between a transformational and a transactional style of leadership in accordance with the situation in order to facilitate knowledge sharing. One might expect that transactional leaders promote the sharing of knowledge, but only to the extent that it clarifies role and task requirements or serve some other clear purpose.

\section{Research Aims}

1. Leaders' transformational leadership is positively correlated with the sharing of knowledge in private secondary schools in Dubai; Transformation leadership being considered through the leadership attributes of:

i. Idealised influence attributes (IIA)

ii. Idealised influence behaviour (IIB)

iii. Inspirational motivation (IM)

iv. Intellectual stimulation (IS)

v. Individualised Consideration (IC)

2. Leaders' transactional leadership is positively correlated with the sharing of knowledge in private secondary schools in Dubai; Transformation leadership being considered through the leadership attributes of:
i. Contingent reward (CR)
ii. Transaction by management exception (active)- (MEA)
iii. Transaction by management exception (passive)- (MEP)
iv. Laissez-faire (LF)

\section{Methodology}

The latent variable approach was employed as the framework of the study. Latent variables are those variables in social and behavioral sciences which are not directly observable. Therefore that variable called Latent variable and the method of analysis would be the latent variable analysis (Bagozzi, 1984). The latent variables in the present study were Knowledge Sharing subscales (the outcome variable) and the predictor latent variables were Transactional Leadership and Transformational Leadership subscales.

The first step of the analysis measured the factor validity of the latent variables, a step that ofter referred to as construct and scale development. At this stage, the initial model will be screened to remove the variables that show no significant relationship to each of the factors. The second step involved modification of the modeled latent variables to test the relationships between the latent variables. 


\section{Data Analysis}

The conceptual model was tested using Partial Least Squares (PLS), a second generation multivariate analytic technique that enables path analytic modeling using latent variables (Wold 1982; Chin 1998). The loadings of items on constructs in a PLS model are the same as factor loadings- path coefficients are standardized regression coefficients, and R2 values describe variance explained in dependent variables. SmartPLS is a component-based path modelling program based on partial least squares (PLS). SEM combines factor analysis with linear regressions and enables the simultaneous examination for the path (Structural) and factor (Measurement) models in one model (Haenlein and Kaplan, 2004). We employed PLS path modelling because it makes fewer demands on assumptions including the underlying data distribution and sample size compared to covariance-based structural equation modelling (Rigdon, 1996).

Tests of reliability and validity were conducted, including those for item reliability, internal consistency, convergent validity, and discriminant validity (Hulland 1999). Path significance was assessed using bootstrap statistics and a123236 D. J. Neufeld et al. blindfold resampling procedure, with a total of 500 resamples and an omission distance of one case per sample (Lohmöller 1984).

\section{Construct Measurement and Validation}

The target respondents were within the schools. The questionnaire was provided in electronic format and respondents were asked to complete it online (through the hyperlink sent to them via email). Principles of the Schools were contacted to gain their support and understanding for the research. The population sample achieved was 223 usable questionnaires. The questions quantified the measured variables using a five-point Likert scale. There were no missing values. The constructs used in this study are five subscales of Transformational leadership with 20 items (Idealized Influence-Behavior, 4 items, Idealized Influence-Attribute, 4 items, Individualized Consideration, 4 items, Inspirational Motivation, 4 items, and Intellectual Stimulation, 4 items. Constructs of Knowledge sharing were also considered through a 19 item scale (Combination 5 items, Externalization 4 items, Internalization 5 items, and Socialization 5 items). While subscales of transactional leadership with 16 items (Contingent Reward, 4 items, Laisser- Faire, 4 items, Management by ExceptionActive, 4 items, and Management by Exception-Passive, 4 items).

Based on this set of approved data, psychometrical properties of the modelled data were calculated, including; convergent validity, discriminant validity, unidimensionality, and reliability of the constructs and the structural model were tested. Variables were checked for any nonsignificant factor loading, none of the items were removed at this stage, and therefore, all of the initial variables were considered in the model. This test ensured that only the strongest measured variables remained in the scales. As a result, all measured variables had significant factor loadings, as the result the levels of average variance extracted (AVE) of the final constructs were all relatively high (between .57 and .83), above the .50 level recommended by Fornell and Larcker (1981). 
The reliability of the constructs was assessed by the levels of Cronbach's Alpha which was compared to the standard threshold of .70 recommended by Nunnally (1978) and the more conservative level of .80 threshold recommended by Straub and Carlsson (1989), the results ranged from .86 to .93 .

In addition, the unidimensionality was measured by estimation of the cross- loadings among the measured variable. Cross loadings are the loadings of each of variables on the other components. For all pairs of constructs, all measured variables for each pair of constructs were expected to be loaded clearly and strongly on their expected construct, without exception and with a good margin of difference between loadings. In summary, a set of valid, reliable constructs was ready to be used to test the structural model in the target sample $(n=223)$. Psychometrical aspects including the validity and reliability tests and the outcomes of the structural model analysis are explained in the next section.

\section{Validity and Reliability}

Results demonstrated satisfactory item reliability, internal consistency, convergent validity and discriminant validity (see Table2). First, loaded at 0.7 or above on their respective constructs, indicating acceptable item reliability (Chin 1998; Carmines and Zeller 1979). Second, internal consistency was well above the commonly used cut off for all multi-item constructs (Nunnally 1978; Van Den Ven 1979). Third, average variance extracted (AVE), a measure of the average amount of variance that a construct captures from its indicators relative to the amount due to measurement error, was well above the 0.5 threshold for all constructs suggesting convergent validity (Fornell and Larcker 1981; Chin 1998). Fourth, items correlated most strongly with intended construct (as shown by loadings and cross-loadings in Table 2), indicating acceptable discriminant validity (Barclay et al. 1995; Wixom and Todd 2005). Also, the average correlation among the measures of each (shown on the diagonal of the correlation matrix of Table 2) was greater than each construct's relationship with any other construct, providing further evidence of discriminant validity. Although a high correlation was observed between the transformational and contingent reward leadership constructs, this finding is consistent with prior empirical studies on leadership (politis, 2001, 2002; Bryant, 2003;Singh,2008) We examined reliability, convergent validity, and discriminant validity for the constructs as follows.

Table 1 provides the AVE, reliability and inter-correlations for each of the constructs in the model. All the scales are reliable; all composite reliability values are good, comfortably exceeding the threshold value of .70 (Nunnally, 1978, Straub et al., 2004).

Comparison of the inter-correlations between constructs and the square-root of AVE confirms discriminant validity (Fornell and Larcker, 1981); in every case (except for Social) the square-root of AVE was higher than inter-correlations with other variables by a significant margin.

In the next step of the structural analysis, we estimated all of the target paths and then the significance of paths was measured using corresponding t-values as calculated by PLS algorithm and the application of bootstrapping respectively in the Smart-PLS 2.0 
software package (Ringle et al., 2005). The 500 runs were selected as the target bootstrapping times with the sample of 223. Figure 1 illustrates the full path model with the final path estimations and t-values (see Table 2).

\section{Structural Model- Summary of Findings}

Two paths were significant at the $\mathrm{p}<.05$ level, they were IC $\Rightarrow$ Externalization, $(\mathrm{B}=-$ $.20, \mathrm{p}<.05$, which addresses the reverse relationship between the two components. The higher is the IC, the lower would be the Externalization and vice versa.

The second significant path was MBEA $=>$ Combination $(B=.14, p<.05)$ and means the positive relationship between MBEA and Combination. The higher was the levels of MBEA, the higher would be the levels of Combination and vice versa.

Six paths were significant at the $\mathrm{p}<.01$ and they were as follows:

$1-\mathrm{CR}=>$ Combination $(\mathrm{B}=.33, \mathrm{p}<.01)$; the effect of $\mathrm{CR}$ on Combination was positive then the higher was the levels of $\mathrm{CR}$, the higher would be the levels of Combination.

2- $\mathrm{CR}=>$ Socialization $(\mathrm{B}=.30, \mathrm{p}<.01)$; the effect of $\mathrm{CR}$ on Socialization was positive then the higher was the levels of $\mathrm{CR}$, the higher would be the levels of Socialization and vice versa.

3- IIIB $\Rightarrow>$ Socialization $(\mathrm{B}=.25, \mathrm{p}<.01)$, the effect of Individualized Consideration on Socialization was positive then the higher was the levels of IIIB, the higher would be the levels of Socialization and vice versa.

4- Intellectual Stimulation $=>$ Externalization $(B=.47, p<.01)$, the effect of Intellectual Stimulation on Externalization was positive then the higher was the levels of Intellectual Stimulation, the higher would be the levels of Externalization and vice versa.

5- Intellectual Stimulation $=>$ Internalization $(B=.40, p<.01)$, the effect of Intellectual Stimulation on Internalization was positive then the higher was the levels of Intellectual Stimulation, the higher would be the levels of Internalization and vice versa.

6- Intellectual Stimulation=> Socialization $(B=.34, p<.01)$, the effect of Intellectual Stimulation on Socialization was positive then the higher was the levels of Intellectual Stimulation, the higher would be the levels of Socialization and vice versa.

These results indicate that transformational and transactional contingent reward leadership and knowledge sharing are positively correlated. In the words of Bryant (2003), that "Transformational leaders may be more effective than transactional leadership in creating, sharing knowledge at the individual and group level, transactional Leaders may be more effective than transformational leadership at exploiting knowledge at the organizational level. Leaders are central in the process of creating, sharing, and exploiting knowledge." 
Table 1: Path Coefficient $\beta$ Path Significance $t(\mathrm{~N}=223)$

\begin{tabular}{|c|c|c|c|c|c|c|c|c|c|c|}
\hline & \multicolumn{5}{|c|}{ Transformational Leadership } & \multicolumn{4}{|c|}{ Transactional Leadership } \\
\hline & & IIA & IB & IM & IS & IC & $\mathrm{CR}$ & MEA & MEP & $\mathrm{LF}$ \\
\hline \multirow{4}{*}{ 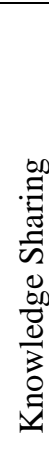 } & Socialisation & . 16 & $\begin{array}{l}.25, \\
P<.01\end{array}$ & -0.11 & $\begin{array}{l}.34, \\
\mathrm{P}<.01\end{array}$ & 0.093 & $\begin{array}{l}.30 \\
\mathrm{P}<.01\end{array}$ & 0.034 & 0.062 & 0.033 \\
\hline & Externalisation & .13 & 0.18 & 0.041 & $\begin{array}{l}.47, \\
P<.01\end{array}$ & $\begin{array}{l}-.20, \\
\mathrm{P}<.05\end{array}$ & 0.21 & 0.001 & 0.103 & 0.066 \\
\hline & Combination & .0 .018 & 0.19 & 0.033 & $\begin{array}{l}.25, \\
\mathrm{P}<.05\end{array}$ & 0.15 & $\begin{array}{l}.33 \\
\mathrm{P}<.01\end{array}$ & $\begin{array}{l}.14, \\
\mathrm{P}<.05\end{array}$ & 0.152 & 0.061 \\
\hline & Internalisation & .0 .025 & 0.14 & 0.063 & $\begin{array}{l}.40, \\
\mathrm{P}<.01\end{array}$ & 0.18 & 0.16 & 0.092 & 0.12 & 0.074 \\
\hline
\end{tabular}

Transformational leadership dimensions sharing

Knowledge

Idealised influence attributes

Idealised influence behaviour

Inspirational motivation

Intellectual stimulation

Individualised consideration

\section{Transactional dimensions}

Contingent reward

Management by exception active

Management by exception passive

Laissez-faire
(IIA)

(IIB)

(IM)

(IS)

(IC)
Socialisation

Externalisation

Combination

Internalisation
(CR)

(MEA)

(MEP)

(LF)

This section addresses research question 1 . The results show that the three dimensions of transformational leadership (Idealised influence behaviour (IIB), Intellectual stimulation (IS), Individualised consideration (IC), all have significant positive relationship with knowledge sharing.

\section{Findings for Transformational Leadership and Knowledge Processes}

Path analysis between the dimensions of transformational and transactional leadership and the dimensions of knowledge sharing revealed that transformational leadership is positively associated with all the dimensions of knowledge sharing. This supports other studies on the impact on transformational leadership on performance (Yammarino et al, 1993; Keller, 1995).

Although it needs to be noted that 3 of the five attributes of transformational leadership were found to be significant in relation to knowledge processes (idealised influence behaviour, intellectual stimulation, and individualized consideration). Different leadership attributes were significant in relation to different knowledge processes. For instance, IIB was significant only when considered with socialisation. 
The exception being leaders' intellectual stimulation leadership, which was shown to be significantly correlated with all dimensions of knowledge sharing (socialisation, externalisation, combination, and internalisation). While Individualised Consideration was shown to be significant for knowledge externalisation.

\section{Idealized Influence Behaviour}

This significance for idealized influence behaviour might be explained by the fact that leaders influence and inspire followers and provide them with energizing and clear sense of purpose, being a role model for ethical conduct, building identification with the leader and his vision (Bass, 1985; Sergiovanni, 1990). Hence, the process of knowledge sharing can be achieved through leaders' idealized behaviour leadership. When considering knowledge processes, the association with all the knowledge attributes was positive, with the socialisation attribute being significant. This may be expected given the tacit to tacit relationship within socialisation.

\section{Intellectual Stimulation}

A significant difference was noted in how intellectual stimulation relates to knowledge processes. Regardless of how it was measured, intellectual stimulation was more highly related than any other leadership style when considering the range of knowledge attributes. Intellectual Stimulation is generally associated with encouraging subordinates to think about problems in new ways. It now seems quite clear that the leader who is able to intellectually stimulate subordinates will amplify knowledge processes.

Leaders through intellectual stimulation help subordinates in re-examining critical assumptions to question whether they are appropriate and seeking differing perspectives when solving problems (Yaseen, 2010). This type of leadership style supports followers as they try new approaches and develop innovative ways of dealing with organizational issues. It encourages followers to think things through on their own, promotes workers' individual efforts, and engages in sharing knowledge and problem solving (Bass, 1985; Sergiovanni, 1990).

In considering the knowledge process attributes at individual, group or organisational level, intellectual stimulation has be shown to be critical for knowledge processes, for both tacit and explicit exchanges.

\section{Individualized Consideration}

Much like Idealised Influence Behaviour, the individualized consideration scale was found to be much more strongly associated with subordinate perceptions of effectiveness as compared with organizational measures of effectiveness. A positive association between Individualized Consideration and effectiveness was consistent across studies (Yaseen, 2010).

Leaders on individualized consideration spend more time coaching, assessing individual needs, and helping team members in developing their strengths (Bass, 
1985; Yaseen, 2010). Seemingly, such transformational qualities do indeed stimulate higher levels needs of followers and result in higher feelings of commitment to share knowledge. Thus, treating each employee in a caring and unique way may give strong motive to trust and collaborate in knowledge sharing (Bass, 1985; Sergiovanni, 1990), and become motivated to transcend their own self-interests for the good of the group or organization (Bass and Avolio, 1990).

Furthermore displaying individualized consideration raises morale and provides teachers with the needed teaching and coaching that will enable them to end their isolation and enhances the sharing of knowledge between teachers (Bass, 1985; Sergiovanni, 1990).

When considering the knowledge process attributes, Individualised Consideration is positively correlated for each of the attributes, but significant for knowledge externalisation. This might be expected given the required task, and the need to encourage individuals to make tacit information explicit.

\section{Transactional Leadership}

This part attempts to answer the second set of research questions. Path analysis between the dimensions of transactional leadership and the dimensions of knowledge sharing revealed that transactional leadership is positively associated with both the dimensions of knowledge sharing;

-Contingent Reward, and

-Management by exception (active)

The findings showed that the attributes of Contingent reward and Management by exception active, are positively correlated with two of the dimensions of knowledge sharing. As was the case for transformational leadership, different leadership attributes were significant in relation to different knowledge processes attributes.

Contingent reward which was shown to be significantly correlated with the knowledge sharing attributes- socialisation, and combination. Management by exception (active) was shown to be significantly correlated with knowledge combination. These are both discussed below.

\section{Contingent Reward}

Surprisingly, and dissimilar to previous findings, not all dimensions of transactional leadership style are related to knowledge sharing. Probably the most interesting result of the study is that the relationship between contingent reward leadership and knowledge sharing is practically equally as strong as the effect of transformational. Hence, this study offers support for the second research question. The classical theoretical arguments presented in the literature review clearly argue that transformational leadership is a much more effective type of leadership in various settings and with various leadership outcomes. However, the results support the more recent theoretical developments of Vera and Crossan (2004) that propose a contingent approach toward leadership and knowledge sharing. 
A factor that may have affected the results of the study is the context. Although in its essence transformational leadership may be universally effective (Bass, 1997; Chen and Lee, 2003), its effectiveness varies across different contexts. Especially in a rapidly changing multicultural environment such as Dubai, where many managers have not been exposed to a wider range of leadership, the kinds of behaviours specified by contingent reward leadership might be relatively more effective than in nations with a long tradition of management practice and science (Chen and Lee, 2003).

In addition to the consideration of leadership styles within the UAE, and more specifically Dubai. It may also be that the context for the study has a unique influence on the results. Knowledge sharing within the educational sector that is, may belong to a group of leadership outcomes for which contingent reward leadership is especially effective.

When considering the knowledge process attributes, CR is positive correlated for each of the attributes, but significant for knowledge socialization and combination. Contingent reward includes leaders clarifying the expectations and presenting recognition when goals are accomplished (Limsila and Ogunlana, 2008; Yukl, 2006). The importance for knowledge processes for socialisation, a tacit to tacit situation, where leaders make clear to individuals expectations. Secondly for combination, an explicit to explicit situation, where organisation wide expectations are set out.

\section{Management by Exception- Active (MEA)}

Where leaders monitor for mistakes or role violations (Northouse, 2007), and take corrective actions before the behaviour makes severe difficulties (Judge and Piccolo, 2004).

In terms of knowledge processes, MEA was seen to be significant for the knowledge attribute combination. MEA may lend itself to this knowledge attribute given the need to set out expectations and monitor these at an organisational level.

This study also revealed that both active and passive management by exception were not correlated with the four dimensions of knowledge sharing.

\section{Summary}

All hypotheses tested show high associations between transformational and transactional leadership and knowledge sharing. The findings showed that three transformational scales are significant: the behavioural version of idealised influence, intellectual stimulation, and individualized consideration. These findings suggest that leaders on idealized influence (behaviour) talk about their values and beliefs more, they specify the importance of having a strong sense of purpose and mission and they consider the moral and ethical consequences of decisions. Leaders on intellectual stimulation help their subordinates re-examine critical assumptions to question whether they are appropriate in order to seek differing perspectives when solving 
problems (Yaseen, 2010). Leaders on individualized consideration spend more time coaching, assessing individual needs, and helping team members in developing their strengths (Yaseen, 2010). Leaders also show significant links to the transactional scales: leadership management by exception (active), when leaders focus their attentions on irregularities, mistakes, exceptions, and deviation from standards. Leaders do not interfere until problems become serious, they react to problems more than looking after problem before they occur, while (70\%) of Arab leaders indicated that they focus their attention on dealing with mistakes, complaints, and failures (Yaseen, 2010). Leadership attributes associated with contingent reward provide assistance for achieving performance targets, and by making clear what one accepts to receive when performance goals are achieved.

Table 2: Correlations between Latent Variables

\begin{tabular}{|c|c|c|c|c|c|c|c|c|c|c|c|c|c|c|c|c|}
\hline & \multirow{2}{*}{$\begin{array}{c}\text { Comp } \\
\text { osite } \\
\text { Reliab } \\
\text { ility }\end{array}$} & \multirow[b]{2}{*}{$\begin{array}{c}\text { Alph } \\
\text { a }\end{array}$} & \multirow[b]{2}{*}{$\begin{array}{c}\mathbf{A V} \\
\mathbf{E}\end{array}$} & \multicolumn{13}{|c|}{ Inter-correlations } \\
\hline & & & & $\begin{array}{c}\text { COM } \\
\text { BIN }\end{array}$ & $\begin{array}{l}\text { C } \\
\text { R }\end{array}$ & $\begin{array}{c}\text { EXTE } \\
\text { RN }\end{array}$ & IC & $\begin{array}{l}\text { II } \\
\text { A }\end{array}$ & $\begin{array}{l}\text { II } \\
\text { B }\end{array}$ & IM & $\begin{array}{c}\text { INTE } \\
\text { RN }\end{array}$ & IS & LF & $\begin{array}{c}\text { MB } \\
\text { EA }\end{array}$ & $\begin{array}{c}\text { MB } \\
\text { EP }\end{array}$ & $\begin{array}{c}\text { SOCI } \\
\text { AL }\end{array}$ \\
\hline $\begin{array}{c}\text { COMB } \\
\text { IN }\end{array}$ & 0.93 & 0.90 & $\begin{array}{r}0.7 \\
2\end{array}$ & 0.85 & & & & & & & & & & & & \\
\hline CR & 0.94 & 0.91 & $\begin{array}{r}0.8 \\
0\end{array}$ & 0.59 & $\begin{array}{l}0 . \\
89\end{array}$ & & & & & & & & & & & \\
\hline $\begin{array}{c}\text { EXTE } \\
\text { RN }\end{array}$ & 0.90 & 0.86 & $\begin{array}{r}0.7 \\
0\end{array}$ & 0.70 & $\begin{array}{r}0 . \\
57\end{array}$ & 0.84 & & & & & & & & & & \\
\hline IC & 0.91 & 0.86 & $\begin{array}{r}0.7 \\
1\end{array}$ & 0.45 & $\begin{array}{r}0 . \\
74\end{array}$ & 0.48 & $\begin{array}{l}0 . \\
84\end{array}$ & & & & & & & & & \\
\hline IIA & 0.95 & 0.93 & $\begin{array}{r}0.8 \\
3\end{array}$ & 0.48 & $\begin{array}{r}0 . \\
59\end{array}$ & 0.57 & $\begin{array}{r}0 . \\
62\end{array}$ & $\begin{array}{l}0 . \\
91\end{array}$ & & & & & & & & \\
\hline IIB & 0.92 & 0.89 & $\begin{array}{r}0.7 \\
5\end{array}$ & 0.51 & $\begin{array}{r}0 . \\
60\end{array}$ & 0.58 & $\begin{array}{r}0 . \\
69\end{array}$ & $\begin{array}{r}0 . \\
77\end{array}$ & $\begin{array}{l}0 . \\
87\end{array}$ & & & & & & & \\
\hline IM & 0.95 & 0.93 & $\begin{array}{r}0.8 \\
2\end{array}$ & 0.48 & $\begin{array}{r}0 . \\
59\end{array}$ & 0.53 & $\begin{array}{r}0 . \\
65\end{array}$ & $\begin{array}{r}0 . \\
81\end{array}$ & $\begin{array}{r}0 . \\
77\end{array}$ & $\begin{array}{l}0 . \\
91\end{array}$ & & & & & & \\
\hline $\begin{array}{c}\text { INTER } \\
\mathbf{N}\end{array}$ & 0.92 & 0.89 & $\begin{array}{r}0.6 \\
9\end{array}$ & 0.74 & $\begin{array}{r}0 . \\
63\end{array}$ & 0.71 & $\begin{array}{r}0 . \\
61\end{array}$ & $\begin{array}{r}0 . \\
56\end{array}$ & $\begin{array}{r}0 . \\
59\end{array}$ & $\begin{array}{r}0 . \\
55\end{array}$ & 0.83 & & & & & \\
\hline IS & 0.93 & 0.90 & $\begin{array}{r}0.7 \\
7\end{array}$ & 0.58 & $\begin{array}{r}0 . \\
75\end{array}$ & 0.67 & $\begin{array}{r}0 . \\
75\end{array}$ & $\begin{array}{r}0 . \\
74\end{array}$ & $\begin{array}{r}0 . \\
75\end{array}$ & $\begin{array}{r}0 . \\
73\end{array}$ & 0.70 & $\begin{array}{l}0 . \\
88\end{array}$ & & & & \\
\hline LF & 0.94 & 0.91 & $\begin{array}{r}0.7 \\
8\end{array}$ & -0.13 & $\begin{array}{r}- \\
0 . \\
25\end{array}$ & -0.23 & $\begin{array}{c}- \\
0 . \\
34\end{array}$ & $\begin{array}{c}- \\
0 . \\
40\end{array}$ & $\begin{array}{c}- \\
0 . \\
37\end{array}$ & $\begin{array}{c}- \\
0 . \\
35\end{array}$ & -0.23 & $\begin{array}{c}- \\
0 . \\
35\end{array}$ & $\begin{array}{l}0 . \\
88\end{array}$ & & & \\
\hline MBEA & 0.94 & 0.92 & $\begin{array}{r}0.8 \\
0\end{array}$ & 0.43 & $\begin{array}{r}0 . \\
48\end{array}$ & 0.34 & $\begin{array}{r}0 . \\
30\end{array}$ & $\begin{array}{r}0 . \\
44\end{array}$ & $\begin{array}{r}0 . \\
33\end{array}$ & $\begin{array}{r}0 . \\
43\end{array}$ & 0.40 & $\begin{array}{r}0 . \\
42\end{array}$ & $\begin{array}{c}0 . \\
01\end{array}$ & 0.89 & & \\
\hline MBEP & 0.95 & 0.93 & $\begin{array}{r}0.8 \\
2\end{array}$ & -0.06 & $\begin{array}{c}- \\
0 . \\
20\end{array}$ & -0.16 & $\begin{array}{c}- \\
0 . \\
30\end{array}$ & $\begin{array}{c}- \\
0 . \\
32\end{array}$ & $\begin{array}{c}- \\
0 . \\
31\end{array}$ & $\begin{array}{c}- \\
0 . \\
31\end{array}$ & -0.15 & $\begin{array}{c}- \\
0 . \\
30\end{array}$ & $\begin{array}{l}0 . \\
82\end{array}$ & 0.02 & $\begin{array}{l}0.9 \\
1\end{array}$ & \\
\hline $\begin{array}{c}\text { SOCIA } \\
\text { L }\end{array}$ & 0.87 & 0.80 & $\begin{array}{r}0.5 \\
7\end{array}$ & 0.72 & $\begin{array}{l}0 . \\
64\end{array}$ & 0.80 & $\begin{array}{r}0 . \\
56\end{array}$ & $\begin{array}{r}0 . \\
61\end{array}$ & $\begin{array}{r}0 . \\
64\end{array}$ & $\begin{array}{r}0 . \\
55\end{array}$ & 0.70 & $\begin{array}{r}0 . \\
69\end{array}$ & $\begin{array}{c}0 . \\
26\end{array}$ & 0.33 & $\begin{array}{r}0.1 \\
9\end{array}$ & 0.75 \\
\hline
\end{tabular}




\section{Conclusions}

On one level the research provides added impetus and support to the combination approach towards leadership styles. Rather than proclaiming one particular leadership style to be the dominant approach, it indicates where a leadership style is more effective for achieving a particular task. In this case it was the attributes for knowledge processes as based on the SECI model. The attainment for each of these SECI stages can be most strongly associated with the following leadership styles;

- Socialisation- Idealised Influence behaviour( .25,p, <01 ), Intellectual stimulation(.34,p<01 ) and Contingent reward(.30,p<.01).

- Externalisation- Intellectual stimulation $(.47, \mathrm{p}<.01$,$) and Individualised$ consideration $(-.20, \mathrm{p}<.05)$

- Combination- Intellectual stimulation(.25,p<.01) Contingent reward(.33,p<.01 )and Management-by-exception (active) $(.14, \mathrm{p}<.05)$

- Internalisation- Intellectual stimulation $(.40, \mathrm{p}<.01)$

It may be further argued that the most effective leadership styles for each of the knowledge processes would be a combination of;

Socialisation IS (.34, P<01); Externalisation- IS (.47,P<.01); Combination- CR (.33, $\mathrm{P}<.01)$; Internalisation- IS (.40,P<.01)

Another possible argument from the findings however, is to argue that in terms of leadership styles, transformational leadership rather than transactional, Managementby-exception, or Laissez-Faire was the only leadership style to be significantly related for each of the knowledge process attributes, based on the attributes from the SECI model. It might be implied, therefore, that overall a transformational approach is more effective than any of the other leadership styles considered. Going a stage further, as Intellectual stimulation was the only leadership attribute to be significant for each of the four SECI knowledge process attributes, it may be argued that Intellectual stimulation is the most relevant leadership attribute within transformational leadership for avhieving knowledge processes in the context.

A dent to this argument is with the level of significance for the knowledge attribute combination. Where although there was a significant relationship for transformational leadership and combination, the level of significance for transactional leadership through contingent reward was shown to be much greater, and hence, arguably, CR would form a more effective leadership style for achieving the knowledge process attribute 'Combination'. Hence justifying the continued argument that a combinational approach for leadership style is still the most effective method.

The findings also highlight the approach for considering leadership in relation to the task, or core process sought. Within this research the focus was on knowledge processes, and the most effective leadership styles for achieving this have been identified. If the focus changes, for instance to creativity or innovation, then the leadership styles that are most effective for achieving this may also change. This develops a need to think beyond what is the most effective leadership style, to what is the most effective combination of leadership styles for a specific task. Before the 
appropriate leadership style can be identified. It would be necessary, therefore, to categorise the different stages of the task, or core processes sought.

Finally, the work offers further support to the distinctive attributes of transformational leadership and transactional leadership. It was stated above; the most significant knowledge attributes were socialisation and combination. Socialisation was significant with 3 leadership attributes, two of these attributes fall under transformational leadership (IIB and IS). Socialisation in the knowledge process emphasises social networking, and the importance of tacit knowledge.

The other knowledge process attribute that was significant with the greatest number of leadership attributes was combination. Combination was also significant with 3 attributes, with two of these coming under transactional leadership (CR and MEA). Combination can be more strongly associated with explicit knowledge.

\section{Contribution- Implications for Managerial Practices}

New information and knowledge is constantly emerging from sources within and outside the company. Channels and conduits for their distribution are evolving. An ever- present pressure to interpret this information in ways that enable emerging business opportunities to be understood and exploited exists (Nonaka and Takeuchi, 1995). The role of leadership in this context is crucial. Leaders need to promote learning at all levels and to create opportunities for people to share knowledge from heterogeneous sources, while leaders have a strong influence on knowledge sharing. Leaders also need to establish opportunities for employees and teachers to share knowledge, to meet and discuss ideas. By emphasizing the company's vision and mission, as well as through personal encouragement and empowerment, leaders can encourage employees to act upon, and support changes that will contribute to the sharing of knowledge.

Secondly, transformational and contingent reward leadership seem equally important for facilitating knowledge sharing. Leaders should, therefore, focus on developing both type of leadership, depending upon the situation. First, they should build respect and trust based on working with individuals, on setting up and defining agreements in order to achieve specific work goals, on clarifying expectations, and on providing rewards for the successful completion of tasks. Only when they have built solid transactional foundations can they extend them by adding typical transformational behaviour that inspire followers to go beyond their self-interest and exert extra effort to achieve the shared vision of becoming a learning organization (Bass, 1985). Leaders should create opportunities for people to meet and talk, be alert to changes in the business environment, and create an open knowledge sharing culture wherein trust and cooperation are core values.

The study findings suggest that both transformational and transactional leadership behaviours are essential to knowledge management process and knowledge sharing in particular. The creation of a successful KM process, however, depends on how well leaders can balance transactional and transformational behaviours. Leaders who choose transactional behaviour will work within current culture and follow existing 
norms, values, and procedures. In this sense, transactional leadership behaviours reinforce current KM practices. Transformational leadership behaviour, in contrast, allows top executives to adapt organizational culture and realign it with the new vision, when needed (Bass, 1985, 1998).

Furthermore, the findings indicate that charisma and contingent reward are the most effective leadership behaviours for knowledge sharing. Leaders should, therefore, focus on developing these leadership behaviours, depending upon the situation. They should build respect and trust based on working with individuals, on setting up and determining agreements in order to achieve specific goals, or clarifying expectations, and on providing rewards for successful completion of tasks or sharing knowledge. Bass (1985) established that transformational and transactional leadership behaviour can be learned through training programs. Thus, there are several implications for managers. First, managers can make their organizations more effective by intentionally managing knowledge. Second, by using an appropriate blend of transformational and transactional leadership styles, managers can increase firms' levels of knowledge sharing. Third, managers that effectively manage knowledge will attract and retain better workers. Finally, firms that are able to better manage their knowledge assets will create a knowledge-sharing environment.

\section{Future Research}

Much greater research needs to be done to test the extent to which the task has an influence on the most appropriate leadership style. To enable this, however, a greater number of tasks will need to be clearly modelled and factors conceptualised to avoid ambiguity and disagreement.

\section{References}

Anderson, J. C. and D. W. Gerbing (1988) "Structural Equation Modeling in Practice: A Review and Recommended Two-Step Approach," Psychological Bulletin (103)3, Fall,pp.411-423.

Antonakis, J., Avolio, B. J., \& Sivasubramaniam, N. (2003). Context and leadership: an examination of the nine-factor full-range leadership theory using the Multifactor Leadership theory using the Multifactor Leadership Questionnaire. The Leadership Quarterly, 14(3), 261-295.

Armandi, B., Oppedisano, J., \& Sherman, H. ( 2003). Leadership theory and practice:a "case" in point. Management Decision, 41 (10), 1076-1088.

Barclay. D.W.Higgins,C, \& Thomson. R. (1995). The partial least squares approach to causal modeling: Personal computer adoption and use as illustration. Technology studies, 2(2), 285-309.

Bass, B.M. (1985). Leadership and performance beyond expectations. New York, NY: The Free Press.

Bass, B.M. (1999). Two decades of research and development in transformational leadership. European Journal of Work and Organizational Psychology, 8(1), 932.

Bass, B.M., \& Avolio, B.J., Jung, D.i., \& Berson, Y. (2003). Predicting unit performance by assessing transformational and transactional leadership. Journal of Appeal Psychology, 88(2), 207-218. 
Bagozzi R., 1984. A prospectus for theory construction in marketing, Journal of Marketing,48(11),-29.

Chin, W.W. 1998. The partial least squares approach for structural equation modelling. In: Marcoulides, G.A. (Ed), Modern Methods for Business Research, Erlbaum, Hillsdale, NJ, 295-336.

Bock, G. W., \& Kim, Y. G. (2002). Breaking the myths of rewards: An exploratory study of attitudes about knowledge sharing. Information Resources Management Journal, 15(2), 14-21.

Certo, S.C., \& Certo, S.T. (2006). Modern management (10 ${ }^{\text {th }}$ ed.). Upper Saddle River, NJ: Pearson Education Inc.

Chen, L. Y. \& Barnes. B. (2006). "Leadership Behaviours and Knowledge sharing in professional service firms engaged in strategic alliances." Journal of Applied Management and Entrepreneurship, Vol. 11(2), p.51.

Chin. W.W. (1998). The partial least squares approach to structural equation modelling: G.A. Marcoulides(Ed). Modern Methods for Business Research. (pp.295-358). Mahwah, N.J: Lawrence Erlbaum Associates.

Constant. D., Kiesler. S. \& Sproull. L. (1994). What's mine is ours, or is it? A study of attitude about information sharing. Information Systems Research, 5(4), 400-422.

Dessler, G. (2004). Management principles and practice for tomorrow's leader ( 3ed.) Upper Saddle River, NJ:Pearson Education Inc.

Epitropaki, O., Martin, R. (2005). The moderating role of individual differences in the relation between transformational/transactional leadership perceptions and organizational identification. The Leadership Quaterly, 16(2005), 569-589.

Felt, J., \& Schyns, B. (2004). Is similarity in leadership related to organizational outcomes? The case of transformational leadership. Journal of Leadership and Organizational studies, 10(4), 92-102.

Fornell C., Larcker D.F., 1981, evaluating structural equation models with unobservable variables and measurement error, Journal of Marketing Research, 18(1), 39-50.

Gefen, and Straub, (2005). "A Practical Guide to Factorial Validity Using PLS-Graph: Tutorial and Annotated example" communications of the association for information systems 16.5 (may 2005):91-109.

Haenlein, and Kaplan (2004), "A beginner's guide to partial least squares analysis," Understanding Statistics, 3 (4), 283.

Hair, J. F., Jr., R. E. Anderson, R. L. Tatham, and W. C. Black (1998) Multivariate Data Analysis with Readings, 5th Edition. Englewood Cliffs, NJ: Prentice Hall.

Hair J.F., Black W.C., Babin B.J., Anderson R.E., Tatham R.L., 2006. Multivariate Data Analysis. New Jersey, Pearson Prentice Hall.

Hulland. J.S. (1999). Use of partial least squares (PLS) in strategic management research: A review of recent studies. Strategic Management Journal. 20(4). 195-204. Partial Least Squares Path Modelling in International Marketing.

Judge, T. A., \& Piccolo, R.F. (2004). Transformational and Transactional Leadership: A Meta-Analytic test of their relative validity. Journal of Applied Psychology, 89(5), 755-768.

Jung, D ., Wu, A., \& Chow, C. W. (2008). Towards understanding the direct and indirect effects of CEO's transformational leadership on firm innovation. The Leadership Quaterly, 19(5), 582-594. 
Keller, R.T. (1992). Transformational leadership and the performance of research and development project groups. Journal of Management. 18: 489-501.

Kinicki, A., \& Kreitner, R. (2008). Organizational behavior: key concepts, skills \& best practices ( $3^{\text {rd }}$ ed.). New York, NY: McGraw-Hill/Irwin.

Kuechler , W. L., McLeod,A., and Simkin, M., G. (2009) empirical research Why don't more students major in is? Decision Sciences Journal of Innovative $\begin{array}{lllll}\text { Education, } & \text { Volume } & 7 & \text { Number } & \text { 2,July2009 }\end{array}$ Nunnally J., 1978. Psychometric Theory, McGraw-Hill, New York.

Lohmoller. J.B. LVPLS Program Manual: Latent Variables Path Analysis with Partial Least- Squares Estimation. Koln-Zentralarchiv fur empirische Sozialiforschung. 1984.

Limsila, K., \& Ogunlana, S.O. (2008). Performance and leadership outcome correlates of leadership styles and subordinate commitment. Engineering, Construction and Architectural Management, 15(2), 164-184.

Leithwood, K., Jantzi, D., \& Steinbach, R. (1999). Changing Leadership for Changin Times. Changing Education Series: Taylor and Francis Group, 7625 Empire Drive, Florence, KY 41042. Tel: 800-634-7064; Fax: 800-245-4742.

Lemon, M., \& Sahota, P. S. (2004). Organizational culture as a knowledge repository for increased innovative capacity. Technovation, 24(6), 483-498.

Levy, P.E., Cober, R..T., \& Miller,T. (2002). The effect of transformational and transactional leadership perceptions on feedback-seeking intentions. Journal of Applied Social Psychology, 32(8), 1703-1720.

Mabey, C., Kulichi, C., \& Loreni-Cioldi, F. (2012). Knowledge Leadership in global scientific research. International Journal of Human Resource Management, 23:6, Special Issue: SI, 2450-2467.

Moss, S.A., \& Ritossa, D.A. (2007). The impact of goal orientation on the association between leadership style and follower performance, creativity and work attitudes. Leadership Organization Development Journal, 3(4), 433-456.

Nezafati, N., Afrazeh, A., \& Jalali, S. M. J. (2009). A dynamic model for measuring knowledge level of organizations based on Nonaka and Takeuchi Model (SECI). Scientific Research and Essays, 4(5), 531-542.

Nonaka, I., \& Takeuchi, H. (1995). The knowledge-creating company: How Japanese companies create the dynamics of innovation: Oxford University Press, USA.

Nonaka, I. (1994). A dynamic theory of organizational knowledge creation. Organization science, 5(1), 14-37.

Northouse, P.G. (2007). Leadership: Theory and practice $\left(4^{\text {th }}\right.$ ed). Thousand Oaks, CA: Sage.

Nunnally. J.C. \& Bernstein. I. H. (1994). Psychometric theory ( $3^{\text {rd }}$ ed). New York. N.Y: McGraw-Hill.

Pierce J.L., \& Newstorm, J.W. (2008). Leaders \& the leadership process: readings, self-assessment $\&$ applications $\left(5^{\text {th }}\right.$ ed.). New York, NY: McGraw-Hill/Irwin.

Pounder, J. S. (2001). "New Leadership" and university organizational effectiveness: exploring the relationship. Leadership \& Organisation Development Journal, 22(6), 281-290.

Rigdon , E., E., ,(1996) CFI versus RMSEA: A comparison of two fit indexes for structural equation modelling. Structural Equation Modelling: A Multidisciplinary Journal Vol. 3, Iss. 4, 1996

Ringle, C.M., Wende, S., Will, A. (2005). SmartPLS 2.0 (beta). Retrieved November 12, 2011 from: http://www.smartpls.de. 
Ringle. C.M., Wende. S., \& Will, A. (2005). Smart-PLS. 2.0 M3. Available at http:// www.smartpls.de.

Sergiovanni, T. J. (1990). Adding Value to Leadership Gets Extra -Ordinary Value in schools. San Francisco.

Shih, H-A., Chiang, Y-H., \& Chen, T-J. (2012). Transformational Leadership, trusting climate, and knowledge-exchange behaviours in Taiwan. The International Journal of Human Resource Management, 23:6, 1057-1073.

Sosik, J. J., Potosky, D., \& Jung, D. I. (2002). Adaptive self-regulation: Meeting others' expectations of leadership and performance. The Journal of Social Psychology, 142(2), 211-232.

Straub D., Carlson C.L., 1989. Validating instruments in MIS research. MIS Quarterly, 13(2), 147-169.

Straub, D., M.-C. Boudreau, and D. Gefen (2004) "Validation Guidelines for IS Positivist Research," Communications of the Association for Information Systems (14) pp. 380-426.

Tickle, E. L., Brownlee, J., \& Nailon, D. (2005). Personal epistemological beliefs and transformational leadership behaviours. Journal of Management Development, 24(8), 706-719.

Vera, D., \& Crossan, M. (2004). Strategic leadership and organizational learning. The Academy of Management Review, 29(2), 222-240.

Verhagena, T.,Dolen, W., (2009) Online purchase intentions: A multi-channel store image perspective. Information \& Management. Volume 46, Issue 2, March.

Yammarino, F. J., Spangler, W. D., \& Bass, B. M. (1993). Transformational leadership and performance: A longitudinal investigation. The Leadership Quarterly, 4(1), 81-102.

Yaseen. Z. (2010). "Leadership styles of men and women in the Arab world". Education, Business and Society: Contemporary Middle Eastern issues, Vol 3 Iss: 1, pp: 63-70.

Yukl, G. (2006). Leadership in organizations $\left(6^{\text {th }}\right.$ ed). Upper Saddle River, NJ: Pearson Education, Inc. 